\title{
Multi-minicore Disease Heinz Jungbluth*
}

\author{
Address: Department of Paediatric Neurology, Evelina Children's Hospital, St. Thomas' Hospital, Lambeth Palace Road, London, SE1 7EH, UK \\ Email: Heinz Jungbluth* - Heinz.Jungbluth@gstt.nhs.uk \\ * Corresponding author
}

Published: 13 July 2007

Orphanet Journal of Rare Diseases 2007, 2:31 doi:10.1 |86/I750-I|72-2-31

This article is available from: http://www.OJRD.com/content/2/I/3I

(C) 2007 Jungbluth; licensee BioMed Central Ltd.

This is an Open Access article distributed under the terms of the Creative Commons Attribution License (http://creativecommons.org/licenses/by/2.0), which permits unrestricted use, distribution, and reproduction in any medium, provided the original work is properly cited.
Received: 30 May 2007

Accepted: 13 July 2007

\begin{abstract}
Multi-minicore Disease $(\mathrm{MmD})$ is a recessively inherited neuromuscular disorder characterized by multiple cores on muscle biopsy and clinical features of a congenital myopathy. Prevalence is unknown. Marked clinical variability corresponds to genetic heterogeneity: the most instantly recognizable classic phenotype characterized by spinal rigidity, early scoliosis and respiratory impairment is due to recessive mutations in the selenoprotein $N$ (SEPNI) gene, whereas recessive mutations in the skeletal muscle ryanodine receptor (RYRI) gene have been associated with a wider range of clinical features comprising external ophthalmoplegia, distal weakness and wasting or predominant hip girdle involvement resembling central core disease (CCD). In the latter forms, there may also be a histopathologic continuum with CCD due to dominant RYRI mutations, reflecting the common genetic background. Pathogenetic mechanisms of $R Y R I$-related $M m D$ are currently not well understood, but likely to involve altered excitability and/or changes in calcium homeoestasis; calcium-binding motifs within the selenoprotein $\mathrm{N}$ protein also suggest a possible role in calcium handling. The diagnosis of $\mathrm{MmD}$ is based on the presence of suggestive clinical features and multiple cores on muscle biopsy; muscle MRI may aid genetic testing as patterns of selective muscle involvement are distinct depending on the genetic background. Mutational analysis of the RYRI or the SEPNI gene may provide genetic confirmation of the diagnosis. Management is mainly supportive and has to address the risk of marked respiratory impairment in SEPN I-related $\mathrm{MmD}$ and the possibility of malignant hyperthermia susceptibility in $R Y R /$-related forms. In the majority of patients, weakness is static or only slowly progressive, with the degree of respiratory impairment being the most important prognostic factor.
\end{abstract}

\section{Disease name(s)}

Multi-minicore Disease; Minicore myopathy; Multicore myopathy; Multiminicore myopathy; Minicore myopathy with external ophthalmoplegia; Multicore myopathy with external ophthalmoplegia; Multiminicore disease with external ophthalmoplegia

\section{Definition}

Multi-minicore Disease $(\mathrm{MmD})$ is an inherited neuromuscular disorder defined by a) multiple areas with reduced oxidative activity running along an only limited extent of the longitudinal axis of the muscle fibre ("minicores") and b) clinical features of a congenital myopathy.

The condition was originally reported in a family with two affected siblings and suggestive histopathological findings [1]; various different designations ("Minicore myopathy", "Multicore myopathy", "Multiminicore myopathy", "Minicore myopathy with external ophthalmoplegia", "Multicore myopathy with external ophthalmoplegia", 
"Multiminicore disease with external ophthalmoplegia") have been assigned to cases with similar histopathological features and reflect the wide variability of both core appearance on muscle biopsy and associated clinical findings.

\section{Epidemiology}

Epidemiological data are only available for the congenital myopathies as a group but not for individual conditions. The incidence of all congenital myopathies is estimated at around $0.06 / 1,000$ live births, or onetenth of all cases of neuromuscular disorders [2]. Regional studies in Northern Ireland [3] and Western Sweden [4] suggest a prevalence between 3.5 - 5.0/100,000 in a Paediatric population.

Forms of MmD due to recessive mutations in the selenoprotein $\mathrm{N}$ (SEPN1) gene are probably rarer than those due to mutations in the skeletal muscle ryanodine receptor (RYR1) gene (personal observation), as mutations in the latter gene appear to be the most common genetic cause of a wide variety of congenital myopathies including central core disease (CCD) [5], certain forms of centronuclear myopathy (CNM) [6] and specific subgroups of MmD.

\section{Clinical description}

Presentation of MmD is usually in infancy or childhood with hypotonia or proximal weakness; prenatal onset with reduced fetal movements and polyhydramnios has also been recognized $[7,8]$. Few cases with onset in adult life have been reported in the premolecular area, occasionally associated with progressive muscle weakness and respiratory or cardiac failure [9-12].

Clinical features associated with minicores on muscle biopsy are markedly heterogeneous:

spinal rigidity, scoliosis and respiratory impairment are the hallmark of the most instantly recognizable, classic phenotype of $\mathrm{MmD}[7,8,13]$; onset is usually early in life and feeding difficulties with failure to thrive may be a presenting feature. A high-pitched voice and myopathic facial features are common, occasionally associated with a higharched or cleft palate. Axial muscle weakness, particularly affecting neck and trunk flexors, is prominent, and failure to acquire head control may be an early sign. Proximal muscle groups, particularly those of the shoulder girdle, are more affected than distal muscles. Muscle wasting mainly affects axial groups, the shoulder girdle and the inner thigh ("bracket-like appearance"). A progressive scoliosis, often associated with lateral trunk deviation, and respiratory impairment have typically evolved by the second decade. Respiratory impairment may lead to secondary cardiac failure $[7,8,14-16]$ and is often grossly out of proportion to the overall degree of weakness.
A subset of patients with a distribution of weakness and wasting similar to the classic phenotype show additional extra-ocular muscle involvement (MmD with external ophthalmoplegia), pronounced on abduction and upward gaze, occasionally evolving over time [7,17-21]. However, respiratory impairment is usually milder than in the classic form, with the exception of the most severely affected neonatal cases [22]. Predominant hip girdle weakness with relative sparing of respiratory and bulbar muscles similar to the pattern in CCD is observed in another subgroup of $\mathrm{MmD}$; some patients may show additional marked distal weakness and wasting, predominantly affecting the hands (moderate form of $\mathrm{MmD}$ with hand involvement) $[23,24]$. As in CCD, exercise-induced myalgia is common, and cryptorchism may be an additional feature in males (personal observation). The pattern of selective involvement on muscle imaging is similar to that observed in classic CCD caused by dominant RYR1 mutations [21,23-25] (Figure 1), and distinct from the selective muscle involvement described in myopathies due to recessive mutations in the SEPN1 gene [26]. The latter two groups may form part of a clinical spectrum rather than distinct entities, as suggested by the observation of extra-ocular muscle involvement evolving over time in patients with the moderate form of MmD [21]. Few severely affected cases have been reported with antenatal onset, generalized arthrogryposis, dysmorphic features and mild to moderate reduction of respiratory function [8].

Respiratory impairment is marked in the classic phenotype of MmD but usually mild or absent in other forms. Cardiac, mainly right ventricular impairment, is usually secondary to marked respiratory involvement [7] and therefore limited to the classic phenotype of $\mathrm{MmD}$; congenital cardiac defects, particularly mitral valve prolapse, have been reported in few patients [1].

The association with malignant hyperthermia $(\mathrm{MH})$ is not as well documented as in CCD due to dominant RYR1 mutations [27], but clinical MH episodes have been recognized in few cases with $\mathrm{MmD}[28,29]$; minicores have also been noted in muscle biopsies from families with MH susceptibility due to RYR1 mutations but no other clinical features of a congenital myopathy [30,31]. Precautions during general anaesthesia such as avoidance of $\mathrm{MH}$-triggering agents such as volatile anaesthetics or muscle relaxants should therefore be taken in $\mathrm{MmD}$ patients, particularly those with likely involvement of the RYR1 gene.

For diagnostic clues to aid the sometimes difficult distinction between SEPN1 - and RYR1-related forms of MmD see Table 1. 


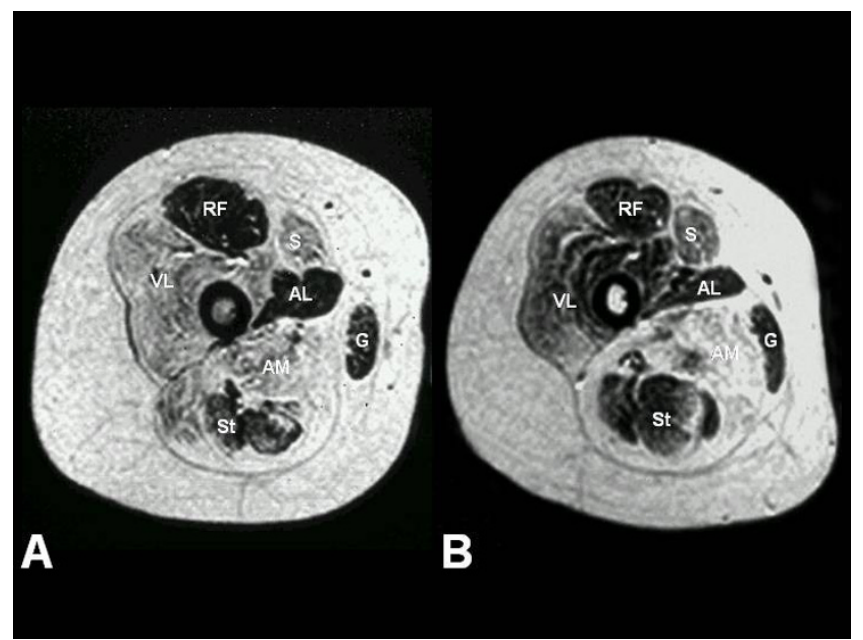

Figure I

Selective muscle involvement in RYRI-related central core disease (CCD) and multi-minicore disease (MmD). Muscle MRI of the thigh, TI-weighted images. A) A transverse section from the proximal thigh in a I2-year-old patient with central core disease (CCD) due to a dominant mutation in the skeletal muscle ryanodine receptor $(R Y R I)$ gene. There is a distinct pattern of selective involvement characterized by marked increase in signal within the vasti, sartorius (S), and adductor magnus (AM), and relative sparing of the rectus femoris (RF), adductor longus ( $A L)$, gracilis $(G)$, and hamstring muscles. B) A transverse section from the proximal thigh in a 17-year-old girl with Multi-minicore disease due to a homozygous recessive RYRI mutation demonstrating a comparable pattern of selective involvement. * Reprinted from [24] Neurology 2002 Jul 23;59(2):284-7. Jungbluth et al.: Autosomal-recessive inheritance of $R Y R I$ mutations in a congenital myopathy with cores. With permission from Lippincott Williams \& Wilkins (LWW).

\section{Aetiology}

The marked clinical variability of $\mathrm{MmD}$ is reflected in genetic heterogeneity: Recessive mutations in both the selenoprotein N (SEPN1) [13] and the skeletal muscle ryanodine receptor ( $R Y R 1)$ gene $[17,23-25,32]$ have been recently identified in clinically distinct subgroups; most reports of dominant inheritance predate molecular resolution of the condition [9,33-38] and may have been due to dominant mutations in the RYR1 gene or other genes giving rise to cores on muscle biopsy.

The selenoprotein N (SEPN1) gene on chromosome 1p36 was considered as a candidate for $\mathrm{MmD}$ because of the considerable clinical and histopathologic overlap between the classic phenotype of $\mathrm{MmD}$ (see paragraph above on clinical description) and congenital muscular dystrophy with rigidity of the spine (RSMD) due to SEPN1 mutations [39]; both conditions share a similar phenotype with marked axial weakness, spinal rigidity, early sco- liosis and respiratory impairment, and histopathologic features of RSMD may be rather more myopathic than dystrophic, with typically a normal creatine kinase (CK). More than 30 SEPN1 mutations associated with a congenital myopathy phenotype have been identified to date and account for around $50 \%$ of cases with the classic phenotype of MmD [13]. SEPN1 mutations in RSMD and MmD are predominantly truncating, with few missense mutations typically affecting functionally important domains of the protein. Homozygous mutations are unexpectedly common even in families from non-consanguineous backgrounds, due to the presence of few founder mutations in different European populations. Selenoprotein N, a glycoprotein localized in the endoplasmic reticulum, belongs to a family of proteins mediating the effect of selenium [for review, [40]] and is involved in various antioxidant defence systems and several metabolic pathways. Abundant expression in fetal muscle precursor cells [41] indicates a role in myogenesis, also supported by the more recent finding of marked myofibrillar alterations in the zebrafish embryo following inhibition of the SEPN1 gene [42]. Although the precise function of selenoprotein $\mathrm{N}$ in muscle remains unclear, possible involvement in calcium homoeostasis is suggested by a structural motif similar to those found in calcium-binding proteins [39].

Clinical subgroups other than the classic phenotype of $\mathrm{MmD}$ have now been associated with recessive homozygous and compound heterozygous mutations in the skeletal muscle ryanodine receptor (RYR1) gene. Homozygous RYR1 mutations have been identified in consanguineous families of different ethnic background with the moderate form (with or without hand involvement) of $\mathrm{MmD}[23,24]$; despite distinct histopathologic appearance, clinical features and findings on muscle imaging were similar to those observed in CCD secondary to heterozygous dominant RYR1 mutations. A cryptic splice site mutation in RYR1 intron 101 was identified in a severely affected isolated case from a consanguineous Tunisian family with $\mathrm{MmD}$ and ophthalmoplegia [22], resulting in a marked depletion of the normal RYR 1 transcript, probably explaining the severe phenotype; both parents were asymptomatic carriers. RYR1 involvement was also suggested by linkage evidence and subsequent mutational analysis in four additional families with $\mathrm{MmD}$ and opthalmoplegia [17], including the original family reported by Swash and Schwartz [18]. In addition to compound heterozygosity for recessive RYR1 mutations in one case, heterozygous RYR1 mutations inherited from an asymptomatic father and expressed on a haploinsufficient background were identified in three families; this has now been attributed to epigenetic allele silencing of the RYR1 gene as a novel mechanism in the pathogenesis of core myopathies [43]. The RYR1 gene is also a likely candidate for the severe form of $\mathrm{MmD}$ with neonatal onset and 
Table I: Clinical and histopathologic features which may aid the distinction between SEPNI-related and RYRI-related forms of Multiminicore disease $(\mathrm{MmD})$.

\begin{tabular}{lll}
\hline Feature & SEPNI-related MmD & RYRI-related MmD \\
\hline Clinical & & ++ \\
Extraocular involvement & - & + \\
Bulbar involvement & + & + \\
Respiratory involvement & +++ & ++ \\
Scoliosis & +++ & + \\
Malignant hyperthermia susceptibility & - & +++ \\
Histopathology & & +++ \\
Type I predominance/uniformity & + & +++ \\
Increase internal nuclei & + & + \\
Multiple large cores ("multicores") & + & ++ \\
Numerous small cores ("minicores") & ++ & \\
\hline
\end{tabular}

$(-)$ = feature not reported, $(+)=$ feature reported, $(++)=$ common feature, $(+++)=$ very common feature

arthrogryposis, considering phenotypic overlap with the form of CCD with fetal akinesia sequence [44].

RYR1 is organized in 106 exons [45] and encodes the skeletal muscle ryanodine receptor (RyR1), the principal, ligand-gated sarcoplasmic reticulum calium release channel with a crucial role in excitation-contraction (E-C) coupling by regulating cytosolic $\mathrm{Ca}^{2+}$ levels. RyR1 calcium release is primarily triggered by voltage-induced conformational changes of the abutting dihydropyridine (DHPR) receptor, and secondarily by a number of exogeneous and endogeneous effector molecules [for review, [46]]. RyR1 N-terminal portions are myoplasmic and constitute the visible foot structure that interacts with the DHPR receptor, whereas the actual calcium release channel is located in the C-terminal part of the protein [47]. The large majority of the more than 100 RYR 1 mutations identified to date were dominant mutations associated with malignant hyperthermia susceptibility (MHS) and central core disease (CCD) phenotypes, typically clustered in the cytoplasmic N-terminal (MHS/CCD region 1, amino acids 35 - 614; mainly MHS), the central (MHS/ CCD region 2, amino acids 2163 - 2458; mainly MHS) and the C-terminal (MHS/CCD region 3, amino acids 4550 - 4940; mainly CCD) domains of the protein [for review, [48]; also [32,49]]. In contrast, recessive RYR1 mutations associated with $\mathrm{MmD}$ have so far only been identified in a small number of families [17,22-24,32] and appear to be distributed throughout the entire RYR1 gene (Figure 2); compound heterozygosity for mutations affecting MHS-related domains of the protein associated with a MmD phenotype has been recognized [17,32]. The majority of MmD-related RYR1 mutations were missense mutations; few intronic splicing mutations have been recently reported $[17,22,32]$.

In contrast to RYR1 mutations associated with CCD and MHS, MmD-associated RYR1 mutations have only been recently studied and specific functional consequences are currently only imperfectly understood. The functional effects of RYR1 mutations associated with CCD and MHS have been extensively investigated in response to the in vitro contracture test (IVCT), in cultured myotubes from patients and in various homologous and heterologous expression systems, resulting in a tentative understanding of the molecular pathophysiology implicated in those phenotypes [for review, [48]]. MH-related RYR1 mutations are thought to result in hypersensitivity of the RyR1 channel, lowering the activation threshold to lower agonist concentrations, whereas CCD-related RYR1 mutations appear to reflect defective intracellular $\mathrm{Ca}^{2+}$ homoeostasis, either due to depletion of intracellular $\mathrm{Ca}^{2+}$ stores ("leaky channel hypothesis") [50] or because of impaired channel efficiency at transporting $\mathrm{Ca}^{2+}$ after activation via depolarization ("E-C uncoupling hypothesis") [51].

The few functional data available to date on MmD-related RYR1 mutations [52-54] suggest a wide variety of pathogenetic mechanisms underlying this phenotype: based on studies of $\mathrm{Ca}^{2+}$ homoeostasis in EBV-immortalized lymphoblasts from patients [52], the previously reported homozygous P3527S substitution [23] was demonstrated to result in decreased stimulated $\mathrm{Ca}^{2+}$ release despite preserved intracellular $\mathrm{Ca}^{2+}$ stores (suggestive of an uncoupled channel), whereas the V4849I substitution [24] was associated with a small but significant effect on resting $\mathrm{Ca}^{2+}$ concentrations. E-C uncoupling was also indicated by complete loss of $\mathrm{Ca}^{2+}$ conductance in recombinant mutant RyR1 channels expressing a Arg109Trp substitution [53] previously associated with a MmD and ophthalmoplegia phenotype [17]. Marked reduction of the amount of the RyR1 protein in some individuals [22,32] suggests that MmD-related RYR1 mutations may affect protein expression and stability as much as function. Additional work will be required to further elucidate the 


\section{CCD}

MmD

R2163H

$57 Y^{*}$

$\int_{\text {G160G }}^{\text {G215E }}$

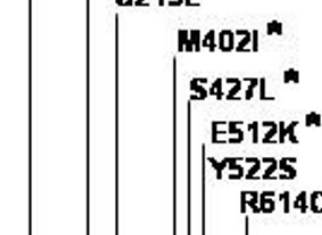

R1094\% *

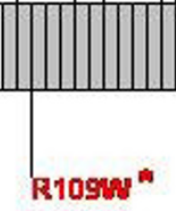

Пगाा

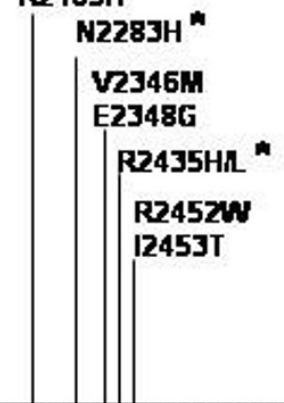

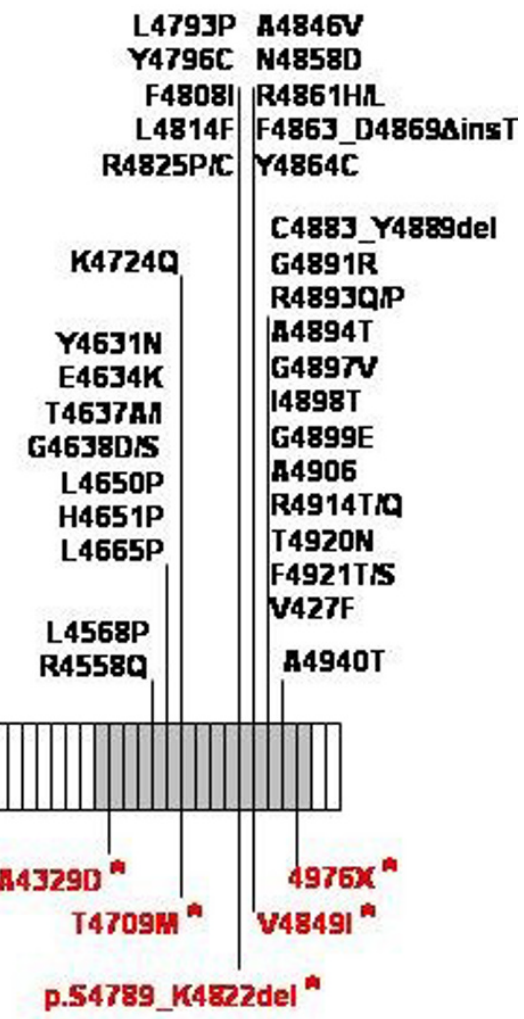

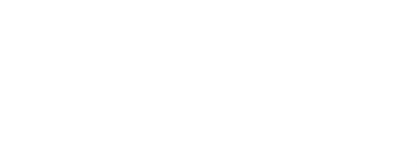

Y4796C

F4808

L4814F

R4825P

4863_D4869\&ins $T$

C4883 Y4889del

G4891R

R4893an

14898

G4899E

A4906

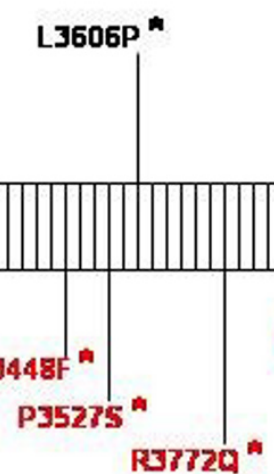

Figure 2

Schematic representation of the skeletal muscle ryanodine receptor (RYRI) gene and distribution of dominant and recessive $(*)$ mutations associated with central core disease (CCD, in black) and Multi-minicore Disease (MmD, in red). Dominant mutations associated with a CCD phenotype predominantly affect the RYRI C-terminal domain encoding the calcium release channel pore of the ryanodine receptor protein, whereas recessive mutations predominantly associated with a MmD phenotype are distributed evenly throughout the gene. $\mathrm{N}$-terminal, central and C-terminal mutational hotspots within the RYRI gene are highlighted in grey. (Figure courtesy of Dr Haiyan Zhou)

molecular mechanisms underlying RYR1-related MmD, and may contribute to the understanding of E-C coupling and RyR1 interactions.

\section{Diagnostic methods}

Multi-minicore Disease (MmD) is a histologic diagnosis established on muscle biopsy. MmD is characterized by multifocal, well-circumscribed areas with reduction of oxidative staining and low myofibrillar ATPase [1].

In contrast to central cores, minicores extend only for a short distance along the longitudinal axis of the muscle fibre, are typically unstructured and may affect both type 1 and type 2 fibres [55]; a peculiar picture described as "focal loss of crossstriations" in muscle fibres has been reported in some families $[18,19]$. Cores may vary substantially in size and morphology (Figure 3), to some extent depending on the genetic background: SEPN1related $\mathrm{MmD}$ is typically associated with numerous small lesions scattered throughout the muscle fibre ("minicores"), whereas multiple larger lesions ("multicores") are more commonly seen in forms of $\mathrm{MmD}$ related to recessive mutations in the RYR1 gene; in the latter group, there may be a continuum with the histopathologic appearance 


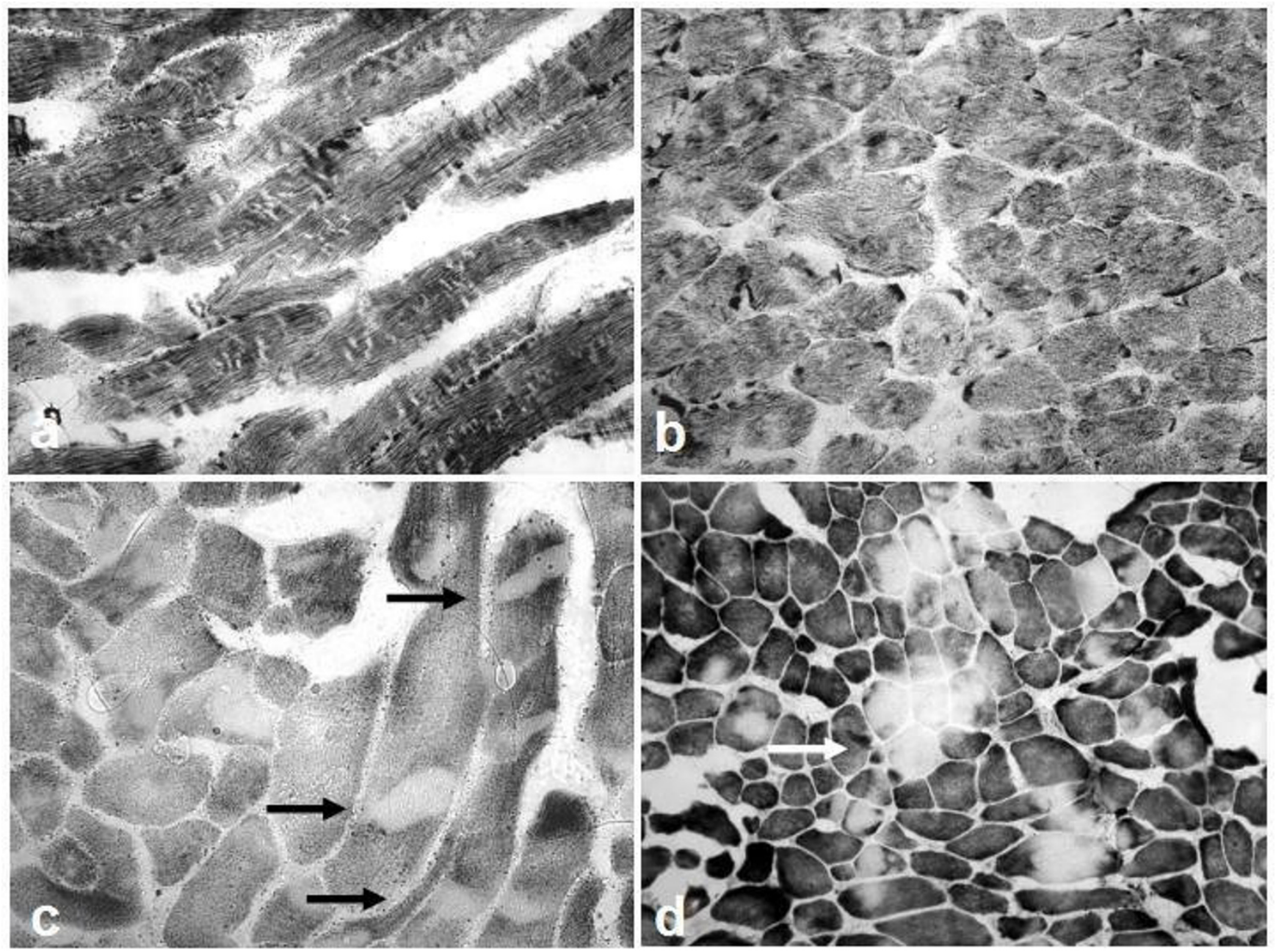

\section{Figure 3}

Histopathological features of Multi-minicore disease. NADH-TR (a-c) and cytochrome oxidase (COX) (d) stains, horizontal $(a, c)$ and transverse $(b, d)$ sections from a 3-year-old $(a-b)$ and a 9-year-old girl $(c-d)$ from different families. Predominance of darker staining type I fibres is prominent in both patients, whilst appearance of core lesions is widely variable, ranging from numerous small lesions of limited extent ("minicores") (a-b) to few multiple large lesions often extending throughout the entire fibre diameter ("multicores") $(\mathrm{c}, \rightarrow$ ) and occasionally affecting the same area in adjacent fibres $(\mathrm{d}, \rightarrow$ ). Whilst "minicores" are more frequently found in SEPN I-related MmD, the latter appearance is more typical of the RYRI-related form and indicates a possible histopathologic continuum with central core disease (CCD) due to mutations in the same gene.

of CCD, occasionally evolving over time as demonstrated in patients on consecutive muscle biopsies [23,56]. Predominance or uniformity of hypotrophic type 1 fibres are commonly associated and may precede the appearance of more specific features $[7,56,57]$; these findings appear to be more commonly observed in cases due to RYR1 mutations compared to SEPN1-related MmD, where fibre typing is often preserved (Sewry, personal observation). A potential overlap with the milder end of the congenital muscular dystrophy spectrum suggested by the observation of whorled fibers, an increase in fat and connective tissue and more dystrophic changes in some individuals $[13,55]$ was recently genetically confirmed by the identifi- cation of recessive SEPN1 mutations in cases of classical $\mathrm{MmD}$ and muscular dystrophy with early rigidity of the spine, a mild form of congenital muscular dystrophy $[13,39]$.

On electron microscopy, minicores present as areas of myofibrillar disruption and paucity of mitochondria, often with degeneration of the sarcomeres and structural changes of the sarcoplasmic reticulum and transverse tubules [55]. The same biopsy may show different stages of minicore formation, ranging from Z-line streaming with preserved myofibrillar structure to areas with complete loss of the sarcomeric architecture [1]. 
Limited immunohistochemical studies in $\mathrm{MmD}$ suggest sarcoplasmic reticulum and desmin abnormalities corresponding to those observed in CCD [58]; as with central cores, minicores stain also strongly positive with antibodies to the actin cross-linking protein filamin $\mathrm{C}$ in a nonspecific manner [59]. A more recent study suggests disturbance of $\mathrm{Ca}^{2+}$-related proteins as a useful immunohistochemical marker to distinguish RYR1-related forms from SEPN1-related forms of $\mathrm{MmD}$ [60].

In cases with equivocal clinical or histopathological features, muscle MR imaging may complement clinical assessment and aid the choice of appropriate genetic testing, as the pattern of selective muscle involvement associated with RYR1 mutations [25] (Figure 1) is distinct from that observed in SEPN1-related cases [26] or other congenital myopathies such as nemaline myopathy [61].

\section{Differential diagnosis}

The finding of cores on muscle biopsy is non-specific and may be observed in a number of different contexts, including clinical conditions with no or little associated weakness and as an additional finding in other neuromuscular disorders.

Minicores as a non-specific finding on muscle biopsy have been reported in healthy probands following eccentric exercise (i.e., lengthening during activity) [62] and on muscle biopsies from families with $\mathrm{MH}$ susceptibility due to RYR1 mutations but no other clinical features of a congenital myopathy $[30,31]$; they may occur in other contexts such as dystrophy, denervation, inflammatory and endocrine myopathies [for review, [1]] and primarily metabolic conditions such as type III glycogenosis [63] or short-chain acyl-CoA dehydrogenase (SCAD) deficiency [64]. It is therefore important to emphasize that the presence of minicores on muscle biopsy without associated weakness or in the presence of other disease causes is not sufficient to constitute a diagnosis of $\mathrm{MmD}$. Single $\mathrm{MmD}$ families have been reported with multiple pterygium syndrome [65] and a complex dysmorphic syndrome featuring short stature, musculoskeletal anomalies, mental retardation, and pituitary hypoplasia with hypogonadotrophic hypogonadism [66]; the genetic basis for this association is currently unclear.

The occurrence of minicores on muscle biopsy in association with features of other congenital myopathies such as central cores, nemaline rods or central nuclei has been well-documented in the pre-molecular era [14,33,67-72] and is currently only partially genetically resolved. Corelike structures, with or without additional nemaline rods, have been reported in association with dominant mutations in the ACTA1 gene $[73,74]$, and there is recent evidence that recessive mutations in the RYR1 gene may give rise to the appearance of centronuclear myopathy with or without additional cores on muscle biopsy [6]. As minicores are thus not specific, the diagnosis of $\mathrm{MmD}$ requires the presence of minicores as the predominant feature on muscle biopsy in conjunction with suggestive clinical features.

The distinction from central core disease (CCD) due to dominant RYR1 mutations may be particularly challenging in the subset of $\mathrm{MmD}$ due to recessive mutations in the same gene, as histopathologic features in the latter groups and CCD may represent part of a continuous histopathologic spectrum rather than distinct entities [56]. However, MmD-associated recessive RYR1 mutations give rise to clinical features such as external ophthalmoplegia, bulbar involvement and a moderate degree of respiratory impairment not commonly observed in typical dominant CCD. Although recessively inherited RYR1 mutations appear to be more closely associated with the histopathologic appearance of $\mathrm{MmD}$ rather than $\mathrm{CCD}$, dominant RYR1 mutations may occasionally give rise to minicores on muscle biopsy [56] and may have accounted for the small number of $\mathrm{MmD}$ pedigrees with apparent autosomal dominant inheritance reported in the pre-molecular area. In addition, the histopathologic appearance of RYR1-related MmD may evolve into the classic picture of CCD on follow-up biopsies later in life [23].

Although cardiac impairment secondary to respiratory involvement is not uncommonly observed in SEPN1related $\mathrm{MmD}$, primary cardiomyopathies have not been reported in genetically confirmed cases of $\mathrm{MmD}$ due to mutations in the SEPN1 or RYR1 genes. However, some myopathies with primary cardiac involvement and a distinct genetic background may feature minicores as an additional histopathologic finding. A rare autosomal dominant myopathy with associated dilated cardiomyopathy and both central and minicores on muscle biopsy has been attributed to mutations in the skeletal muscle $\alpha$ actin (ACTA1) gene [74], whereas autosomal recessive mutations in the titin (TTN) gene were recently identified in a novel early-onset myopathy with minicores, increased central nuclei, dystrophic features and a fatal cardiomyopathy [75].

In addition, prominent desmin accumulation in skeletal and cardiac muscle fibres from other patients with minicores on muscle biopsy and a primary cardiomyopathy [76] may point to primary involvement of the desmin (DES) or related genes; also, mutations in the lamin $\mathrm{A} / \mathrm{C}$ (LMNA) gene, a common cause of various muscular dystrophy and cardiac phenotypes [for review, [77]], may also be associated with core-like structures on muscle biopsy and have to be considered in cases with minicores and prominent cardiac involvement. It is likely that the 
few families with primary cardiomyopathies in association with minicores on muscle biopsy reported in the premolecular area $[9,11,34,76,78]$ may have carried mutations in above genes rather than the SEPN1 and RYR1 genes now firmly associated with $\mathrm{MmD}$.

\section{Management}

No curative treatment is currently available for $\mathrm{MmD}$ and management is mainly supportive based on a multidisciplinary approach.

Regular physiotherapy is aimed at promoting endurance, preservation of muscle function and the prevention of contractures, particularly those of the tendon Achilles. Marked axial involvement is common, particularly in the classic form of MmD secondary to SEPN1 mutations, and exercises promoting truncal stability such as swimming and riding [79] may be particularly recommended. Scoliosis is almost invariable in the classic form of $\mathrm{MmD}$ and in most cases eventually will have to be managed surgically, considering that conservative approaches are often unsuccessful due to the progressive nature of the deformity. As in other neuromuscular conditions, mobilization following surgery ought to be early in order to avoid the detrimental effects of prolonged immobilization on muscle strength. Independent ambulation may be promoted by appropriate rehabilitative measures such as provision of weight bearing calipers in the most severe cases where walking can not be achieved without additional support.

Severe respiratory impairment is almost invariable in the classic phenotype of $\mathrm{MmD}$ secondary to SEPN1 mutations and has to be anticipated with a high degree of suspicion, as most patients remain independently mobile with only little functional impairment whilst already developing respiratory failure $[7,8]$. Patients have to be specifically questioned for symptoms suspicious of nocturnal hypoventilation such as early morning headaches, loss of appetite and daytime drowsiness; respiratory capacity ought to be monitored regularly and annual overnight oxygen saturation studies performed if forced vital capacity (FVC) is less than $60 \%$ of the expected value, and more frequently if FVC is less than $40 \%$ [80]. Respiratory impairment in other forms of $\mathrm{MmD}$ due to RYR1 mutations is usually less severe or absent, but considering the not negligible risk monitoring of respiratory function according to the principles outlined above is advisable. In all forms of $\mathrm{MmD}$, respiratory infections should be treated actively.

Right ventricular impairment secondary to respiratory failure has been reported in the classic phenotype of $\mathrm{MmD}$ and patients with those clinical features ought to have regular cardiac assessments including cardiac ultrasounds. A primary cardiomyopathy has not yet been reported in patients with confirmed mutations in the
SEPN or RYR1 genes; however, cores on muscle biopsy are non-specific and may be found as an additional feature in patients with primary cardiomyopathies due to mutations in the DES, TTN, LMNA and ACTA1 genes (see paragraph on differential diagnosis). Cardiac ultrasound studies therefore ought to be considered in cases where clinical features are unusual and mutations in the SEPN1 and RYR1 genes have been excluded.

Patients with MmD secondary to mutations in the RYR1 gene may be at risk of malignant hyperthermia reactions, an abnormal response to muscle relaxants such as succinylcholine and volatile anaesthetics $[27,81]$, as has been reported in few cases $[28,29]$; minicores on muscle biopsy have also been noticed in few patients with RYR1-related MH susceptibility but no other clinical features of a congenital myopathy [30,31]. Although the association with MH susceptibility is not as clearly documented as in CCD and has been excluded by in vitro contracture testing in some families [23], precautions such as avoidance of potentially MH-triggering agents and availability of the RyR1 antagonist dantrolene should be taken during general anaesthesia.

The $\beta$-agonist salbutamol has been recently studied as a pharmacological agent in the treatment of RYR1-related myopathies with encouraging results [82], however, results of this pilot study will have to be validated in a larger randomized controlled trial as a basis for future recommendations.

\section{Genetic counselling}

Genetic counselling should be offered to all families and individuals in whom a diagnosis of $\mathrm{MmD}$ has been made. SEPN1-related MmD and the majority of cases associated with mutations in the RYR1 gene are inherited as an autosomal recessive trait; only few families with multi-minicores on muscle biopsy and dominant inheritance have been documented.

Mutational analysis of the SEPN1 gene is now offered as a diagnostic service in most countries. Diagnostic RYR1 screening of selected exons has been established for malignant hyperthermia patients by a number of laboratories associated with the European Malignant Hyperthermia Group (EMHG) [83] however, patients with $\mathrm{MmD}$ are likely to require sequencing of the entire RYR1 coding sequence currently not widely available. Unlike mutations associated with a CCD phenotype, MmD-related RYR1 mutations appear to be distributed throughout the RYR1 coding sequence $[17,32]$ and a mutational strategy focusing on mutational hotspots is therefore not feasible. The recent finding of haploinsufficiency secondary to epigenetic allele silencing in RYR1-related phenotypes [43] poses a particular challenge and should prompt screening 
of muscle-derived cDNA in cases where an affected child has inherited a mutation from an unaffected parent.

\section{Prognosis}

Respiratory impairment is the main prognostic factor in SEPN1-related MmD and has to be managed pro-actively; patients can usually be maintained on nocturnal noninvasive ventilation for many years without major functional deterioration.

The forms of MmD due to recessive RYR1 mutations are usually associated with a mild to moderate degree of disability and carry an overall favourable prognosis, and, with the exception of the most severely affected neonatal cases, almost all patients achieve the ability to walk independently. The course of RYR1-related MmD in childhood and adolescence is static or only slowly progressive $[17,32]$, but the absence of larger long term follow-up series makes it difficult to comment on the further course into adulthood.

\section{Unresolved questions}

The precise molecular mechanisms underlying $\mathrm{MmD}$ are currently only partially understood. Recent limited functional studies suggest that recessive RYR1 mutations may affect function of the tetrameric RyR1 protein only in the homozygous state; this may be modulated through the effect on the binding of accessory and regulatory proteins involved in channel kinetics. More extensive functional studies are required to further delineate specific genotypephenotype correlations in $\mathrm{MmD}$ and are likely to advance our understanding of excitation-contraction (E-C) coupling as a potential basis for future rational therapeutic approaches.

While the functional effects of RYR1 mutations associated with CCD, MHS and MmD are at least partially understood, the precise molecular mechanisms in the pathogenesis of SEPN1-related $\mathrm{MmD}$ remains unclear; a calcium-binding motif within the selenoprotein $\mathrm{N}$ protein suggests that intracellular $\mathrm{Ca}^{2+}$ handling may also be affected in this subgroup of $\mathrm{MmD}$ and points at a common pathway in the pathogenesis of core formation.

A proportion of patients with typical features of $\mathrm{MmD}$ do not harbour mutations in the RYR1 or SEPN1 genes and this group is still awaiting genetic resolution.

\section{References}

I. Engel AG, Gomez MR, Groover RV: Multicore disease. Mayo Clin Proc 197I, 10:666-68I.

2. Wallgren-Pettersson C: Congenital nemaline myopathy: a longitudinal study. Volume 30 . Academic dissertation, University of Helsinki, Commentationes Physico-Mathematicae III/Dissertationes; 1990: 102.

3. Hughes MI, Hicks EM, Nevin NC, Patterson VH: The prevalence of inherited neuromuscular disease in Northern Ireland. Neuromuscul Disord 1996, 6:69-73.
4. Darin N, Tulinius M: Neuromuscular disorders in childhood: a descriptive epidemiological study from Western Sweden. Neuromuscul Disord 2000, 10: I-9.

5. Zhang Y, Chen HS, Khanna VK, DeLeon S, Phillips MS, Schappert K, Britt BA, Browell AK, MacLennan DH: A mutation in the human ryanodine receptor associated with central core disease. Nature Genetics 1993, 5:46-50.

6. Jungbluth $H$, Zhou $H$, Sewry $C A$, Robb $S$, Treves $S$, Bitoun $M$, Guicheney P, Buj-Bello A, Bonnemann C, Muntoni F: Centronuclear myopathy due to a de novo dominant mutation in the skeletal muscle ryanodine receptor (RYRI) gene. Neuromuscul Disord 2007, 17:338-345.

7. Jungbluth H, Sewry C, Brown SC, Manzur AY, Mercuri E, Bushby K, Rowe P, Johnson MA, Hughes I, Kelsey A, Dubowitz V, Muntoni F: Minicore myopathy in children - A clinical and histopathological study of 19 cases. Neuromuscul Disord 2000, 10:264-273.

8. Ferreiro A, Estournet B, Chateau D, Ferreiro A, Estournet B, Chateau D, Romero NB, Laroche C, Odent S, Toutain A, Cabello A, Fontan D, dos Santos HG, Haenggeli CA, Bertini E, Urtizberea JA, Guicheney $P$, Fardeau M: Multi-minicore disease - searching for boundaries: phenotype analysis of $\mathbf{3 8}$ cases. Ann Neurol 2000, 48:745-757.

9. Shuaib A, Martin JME, Mitchell LB, Brownell AKW: Multicore myopathy: not always a benign entity. Can J Neurol Sci 1988, 15:10-14.

10. Bonnette $\mathrm{H}$, Roelofs $\mathrm{R}$, Olson WH: Multicore disease: report of a case with onset in middle age. Neurology 1974, 24:1039-1044.

1I. Magliocco AM, Mitchell LB, Brownell AK, Lester WM: Dilated cardiomyopathy in multicore myopathy. Am J Cardiol 1989, 63:150-15|.

12. Zeman AZJ, Dick DJ, Anderson JR, Watkin SW, Smith IE, Shneerson JM: Multicore myopathy presenting in adulthood with respiratory failure. Muscle Nerve 1997, 20:367-369.

13. Ferreiro A, Quijano-Roy S, Pichereau C, Moghadaszadeh B, Goemans $\mathrm{N}$, Bonnemann $\mathrm{C}$, Jungbluth $\mathrm{H}$, Straub $V$, Villanova $M$, Leroy JP, Romero NB, Martin JJ, Muntoni F, Voit T, Estournet B, Richard P, Fardeau M, Guicheney P: Mutations of the selenoprotein $\mathbf{N}$ gene, which is implicated in rigid spine muscular dystrophy, cause the classical phenotype of multiminicore disease: reassessing the nosology of early-onset myopathies. Am J Hum Genet 2002, 71:739-749.

14. Fitzsimons RB, McLeod JG: Myopathy with pathological features of both centronuclear myopathy and multicore disease. J Neurol Sci 1982, 57:395-405.

15. Rimmer KP, Whitelaw WA: The respiratory muscles in multicore myopathy. Am Rev Res Dis 1993, I 48(I):227-23I.

16. Rowe PW, Eagle M, Pollitt C, Bullock RE, Bushby KMD: Multicore myopathy: respiratory failure and paraspinal muscle contractures are important complications. Dev Med Child Neurol 2000, 42:340-343.

17. Jungbluth $\mathrm{H}$, Zhou $\mathrm{H}$, Hartley L, Halliger-Keller B, Messina S, Longman C, Brockington M, Robb SA, Straub V, Voit T, Swash M, Ferreiro A, Bydder G, Sewry CA, Muller C, Muntoni F: Minicore myopathy with ophthalmoplegia caused by mutations in the ryanodine receptor type I gene. Neurology 2005, 65:1930-1935.

18. Swash M, Schwartz MS: Familial multicore disease with focal loss of crosstriations and ophthalmoplegia. J Neurol Sci 198I, 52: $1-10$.

19. van Wijngaarden GK, Bethlem J, Dingemans KP, Coers C, TelermanToppet N, Gerard JM: Familial focal loss of cross striations. J Neurol 1977, 216:163-172.

20. Gordon PH, Hays AP, Rowland LP, Dickoff DJ, Schotland DL, Rosenberg RN, Wolfe DE, Lange DJ, Lovelace RE: Erroneous diagnosis corrected after 28 years. Not spinal muscular atrophy with ophthalmoplegia but minicore myopathy. Arch Neurol 1996, 53:1194-1196.

21. Jungbluth H, Beggs A, Bonnemann C, Bushby K, Ceuterick-de Groote C, Estournet-Mathiaud B, Goemans N, Guicheney P, Lescure A, Lunardi J, Muntoni F, Quinlivan R, Sewry C, Straub V, Treves S, Ferreiro A: I I Ith ENMC International Workshop on Multi-minicore Disease. 2nd International MmD Workshop, 9-II November 2002, Naarden, The Netherlands. Neuromuscul Disord 2004, I 4:754-766.

22. Monnier N, Ferreiro A, Marty I, Labarre-Vila A, Mezin P, Lunardi J: A homozygous splicing mutation causing a depletion of skeletal muscle RYRI is associated with multi-minicore disease 
congenital myopathy with ophthalmoplegia. Hum Mol Genet 2003, I 2: II7I-1 I78.

23. Ferreiro $A$, Monnier N, Romero NB, Leroy JP, Bonnemann $C$, Haenggeli CA, Straub V, Voss WD, Nivoche $Y$, Jungbluth $H$, Lemainque A, Voit T, Lunardi J, Fardeau M, Guicheney P: A recessive form of central core disease, transiently presenting as multiminicore disease, is associated with a homozygous mutation in the ryanodine receptor type I gene. Ann Neurol 2002, 5I:750-759.

24. Jungbluth $\mathrm{H}$, Müller CR, Halliger-Keller B, Brockington M, Brown SC, Feng L, Chattopadhyay A, Mercuri E, Manzur AY, Ferreiro A, Laing NG, Davis MR, Roper HP, Dubowitz V, Bydder G, Sewry CA, Muntoni F: Autosomal-recessive inheritance of RYRI mutations in a congenital myopathy with cores. Neurology 2002, 59:284-287.

25. Jungbluth $\mathrm{H}$, Davis MR, Muller C, Counsell S, Allsop J, Chattopadhyay A, Messina S, Mercuri E, Laing NG, Sewry CA, Bydder G, Muntoni F: Magnetic resonance imaging of muscle in congenital myopathies associated with RYRI mutations. Neuromuscul Disord 2004 14:785-790.

26. Mercuri E, Talim B, Moghdaszadeh B, Petit N, Brockington M, Counsell S, Guicheney P, Muntoni F, Merlini L: Clinical and imaging findings in six cases of congenital muscular dystrophy with rigid spine syndrome linked to chromosome Ip (RSMDI). Neuromuscul Disord 2002, I 2:631-638.

27. Denborough MA, Dennett $X$, Anderson RM: Central-core disease and malignant hyperpyrexia. $\mathrm{Br}$ Med | 1973, I:272-273.

28. Koch BM, Bertorini TE, Eng GD, Boehm R: Severe multicore disease associated with reaction to anaesthesia. Arch Neurol 1985 , 42:1204-1206.

29. Osada H, Masuda K, Seki K, Sekiya S: Multi-minicore disease with susceptibility to malignant hyperthermia in pregnancy. Gynecol Obstet lnvest 2004, 58:32-35.

30. Barone $V$, Massa O, Intravaia E, Bracco A, Di Martino A, Tegazzin V, Cozzolino S, Sorrentino V: Mutation screening of the RYRI gene and identification of two novel mutations in Italian malignant hyperthermia families. J Med Genet 1999, 36:115-118.

31. Guis S, Figarella-Branger D, Monnier N, Bendahan D, Kozak-Ribbens G, Mattei JP, Lunardi J, Cozzone PJ, Pellissier JF: Multiminicore disease in a family susceptible to malignant hyperthermia: histology, in vitro contracture tests, and genetic characterization. Arch Neurol 2004, 6 I: 106-II3.

32. Zhou $H$, Jungbluth $H$, Sewry CA, Feng L, Bertini E, Bushby K, Straub V, Roper H, Rose MR, Brockington M, Kinali M, Manzur A, Robb S, Appleton R, Messina S, D'Amico A, Quinlivan R, Swash M, Muller CR, Brown S, Treves S, Muntoni F: Molecular mechanisms and phenotypic variation in RYRI-related congenital myopathies. Brain in press. 2007 May 4;

33. Bethlem J, Arts WF, Dingemans KP: Common origin of rods, cores, miniature cores, and focal loss of cross-striations. Arch Neurol 1978, 35:555-566.

34. Bender AN: Congenital myopathies. p.I. In Handbook of Clinical Neurology Diseases of Muscle Part II Volume 4I. Edited by: Vinken PJ, Bruyn GW. NorthHolland, Amsterdam; 1979.

35. Brownell AKW: Familial multicore disease. Trans Am Neurol Assoc 1979, 104:130-133.

36. Vanneste JA, Stam FC: Autosomal dominant multicore disease. J Neurol Neurosurg Psychiatry 1982, 45:360-365.

37. Paljaervi L, Kalimo H, Lang H, Savontaus M-L, Sonninen V: Minicore myopathy with dominant inheritance. J Neurol Sci 1987, 77:II-22.

38. Yoshida T, Morita M, Yamanouchi Y, Okamoto K, Hirai S: A family with multicore disease. Muscle Nerve 1993, 16:568-569.

39. Moghadaszadeh B, Petit N, Jaillard C, Brockington M, Roy SQ, Merlin L, Romero N, Estournet B, Desguerre I, Chaigne D, Muntoni F, Topaloglu $H$, Guicheney P: Mutations in SEPNI cause congenital muscular dystrophy with spinal rigidity and restrictive respiratory syndrome. Nat Genet 200I, 29:17-18.

40. McKenzie RC, Arthur JR, Beckett G]: Selenium and the regulation of cell signaling, growth, and survival: molecular and mechanistic aspects. Antioxid Redox Signal 2002, 4:339-35I.

4I. Petit N, Lescure A, Rederstorff M, Krol A, Moghadaszadeh B, Wewer UM, Guicheney P: Selenoprotein N: an endoplasmic reticulum glycoprotein with an early developmental expression pattern. Hum Mol Genet 2003, 12:1045-1053.
42. Deniziak $M$, Thisse $C$, Rederstorff $M$, Hindelang $C$, Thisse $B$, Lescure A: Loss of selenoprotein $\mathbf{N}$ function causes disruption of muscle architecture in the zebrafish embryo. Exp Cell Res 2007, 13:156-167.

43. Zhou $H$, Brockington M, Jungbluth $H$, Monk D, Stanier P, Sewry CA, Moore GE, Muntoni F: Epigenetic allele silencing unveils recessive RYR I mutations in core myopathies. Am J Hum Genet 2006, 79:859-868.

44. Romero NB, Monnier N, Viollet L, Cortey A, Chevallay M, Leroy JP, Lunardi J, Fardeau M: Dominant and recessive central core disease associated with RYRI mutations and fetal akinesia. Brain 2003, I 26:234|-2349.

45. Phillips MS, Fujii J, Khanna VK, DeLeon S, Yokobata K, de Jong P, MacLennan D: The structural organization of the human skeletal muscle ryanodine receptor (RYRI) gene. Genomics 1996 , 34:24-4I.

46. Meissner G: Regulation of mammalian ryanodine receptors. Front Biosci 2002, 7:d2072-2080.

47. Wagenknecht T, Grassucci R, Frank J, Saito A, Inui M, Fleischer S: Three dimensional architecture of the calcium channel/foot structure of sarcoplasmic reticulum. Nature 1989, 338: $167-170$.

48. Treves S, Anderson AA, Ducreux S, Divet A, Bleunven C, Grasso C Paesante S, Zorzato F: Ryanodine receptor I mutations, dysregulation of calcium homeostasis and neuromuscular disorders. Neuromuscul Disord 2005, 15:577-587.

49. Wu S, Ibarra MC, Malicdan MC, Murayama K, Ichihara Y, Kikuchi H, Nonaka I, Noguchi S, Hayashi YK, Nishino I: Central core disease is due to RYRI mutations in more than $\mathbf{9 0 \%}$ of patients. Brain 2006, I 29: I 470-1480

50. Tong J, McCarthy TV, MacLennan DH: Measurement of resting cytosolic $\mathrm{Ca2}+$ concentrations and $\mathrm{Ca2}+$ store size in HEK293 cells transfected with malignant hyperthermia or central core disease mutant $\mathrm{Ca}+$ release channels. J Biol Chem 1999, 274:693-702.

51. Dirksen RT, Avila G: Altered ryanodine receptor function in central core disease: leaky or uncoupled $\mathrm{Ca}(2+)$ release channels? Trends Cardiovasc Med 2002, I 2:189-197.

52. Ducreux S, Zorzato F, Ferreiro A, Jungbluth $H$, Muntoni $F$, Monnier $\mathrm{N}$, Muller CR, Treves S: Functional properties of ryanodine receptors carrying three amino acid substitutions identified in patients affected by multi-minicore disease and central core disease, expressed in immortalized lymphocytes. Biochem J 2006, 395:259-266.

53. Zhou H, Yamaguchi N, Xu L, Wang Y, Sewry C, Jungbluth H, Zorzato F, Bertini E, Muntoni F, Meissner G, Treves S: Characterization of recessive RYR I mutations in core myopathies. Hum Mol Genet 2006, I5:279|-2803.

54. Zorzato F, Jungbluth $\mathrm{H}$, Zhou H, Muntoni F, Treves S: Functional effects of mutations identified in patients with multiminicore disease. IUBMB Life 2007, 59:14-20.

55. Dubowitz V, Sewry CA: Muscle biopsy - A practical approach 3rd edition. WB Saunders, London; 2006.

56. Sewry CA, Muller C, Davis M, Dwyer JS, Dove J, Evans G, Schroder $R$, Furst $D$, Helliwell $T$, Laing $N$, Quinlivan RC: The spectrum of pathology in central core disease. Neuromuscul Disord 2002 12:930-938.

57. Jongpiputvanich S, Walsh PJ, Kakulas BA: Minicores and congential fibre type disproportion observed in a family. J Paediatr Child Health 1995, 31:253-257.

58. Sewry CA: The role of immunocytochemistry in congenital myopathies. Neuromuscul Disord 1998, 8:394-400.

59. Bonnemann CG, Thompson TG, van der Ven PF, Goebel HH, Warlo I, Vollmers B, Reimann J, Herms ], Gautel M, Takada F, Beggs AH, Furst DO, Kunkel LM, Hanefeld F, Schroder R: Filamin C accumulation is a strong but nonspecific immunohistochemical marker of core formation in muscle. I Neurol Sci 2003, 206:7I-78.

60. Herasse M, Parain K, Marty I, Monnnier N, Kaindl AM, Leroy JP, Richard $\mathrm{P}$, Lunardi J, Romero NB, Ferreiro A: Abnormal distribution of calcium-handling proteins: a novel distinctive marker in core myopathies. J Neuropathol Exp Neurol 2007, 66:57-65.

61. Jungbluth H, Sewry CA, Counsell S, Allsop J, Chattopadhyay A, Mercuri E, North K, Laing N, Bydder G, Pelin K, Wallgren-Pettersson C, Muntoni F: Magnetic resonance imaging of muscle in nemaline myopathy. Neuromuscul Disord 2004, 14:779-784. 
62. Nurenberg P, Giddings C, Stray-Gundersen J, Fleckenstein JL, Gonyea WJ, Peshock RM: MR imaging guided muscle biopsy for correlation of increased signal intensity with ultrastructural change and delayed-onset muscle soreness after exercise. Radiology 1992, 184:865-869.

63. Pellissier JF, de Barsy T, Faugere MC, Rebuffel P: Type III glycogenosis with multicore structures. Muscle Nerve 1979, 2:124-132.

64. Tein I, Haslam RH, Rhead WJ, Bennett MJ, Becker LE, Vockley J: Short-chain acyl-CoA dehydrogenase deficiency: a cause of ophthalmoplegia and multicore myopathy. Neurology 1999, 52:366-372.

65. Ohkubo M, Ino T, Shimazaki S, Yabuta K, Okada R, Sato T: Multicore myopathy associated with multiple pterygium syndrome and hypertrophic cardiomyopathy. Pediatr Cardiol 1996, 17:53-56.

66. Chudley AE, Rozdilsky B, Houston CS, Becker LE, Knoll JH: Multicore disease in sibs with severe mental retardation, short stature, facial anomalies, hypoplasia of the pituitary fossa and hypogonadotrophic hypogonadism. Am J Med Genet 1985, 20:145-158

67. Lee YS, Yip WCL: A fatal congenital myopathy with severe type I fibre atrophy, central nuclei and multicores. J Neurol Sci 1981, 50:277-290.

68. Hulsmann N, Gullotta F, Okur H: Cytopathology of an unusual case of centronuclear myopathy. J Neurol Sci I 98I, 50:3 I I-333.

69. Vallat JM, de Lumley L, Loubet A, Leboutet MJ, Corvisier N, Umdenstock R: Coexistence of minicores, cores, and rods in the same muscle biopsy. A new example of mixed congenital myopathy. Acta Neuropathol (Berl) 1982, 58:229-232.

70. Thomas C: Nemaline rod and central core disease: a coexisting Z-band myopathy. Muscle Nerve 1997, 20:893-896.

71. Scacheri PC, Hoffman EP, Fratkin JD, Semino-Mora C, Senchak A, Davis MR, Laing NG, Vedanarayanan V, Subramony SH: A novel ryanodine receptor mutation causing both cores and rods in congenital myopathy. Neurology 2000, 55:1689-1696.

72. Monnier N, Romero NB, Lerale J, Landrieu P, Nivoche Y, Fardeau M, Lunardi J: Familial and sporadic forms of central core disease are associated with mutations in the C-terminal domain of the skeletal muscle ryanodine receptor. Hum Mol Genet 200I, I 0:258I-2592.

73. Jungbluth H, Sewry CA, Brown SC, Nowak KJ, Laing NG, WallgrenPettersson C, Pelin K, Manzur AY, Mercuri E, Dubowitz V, Munton $\mathrm{F}$ : Mild phenotype of nemaline myopathy with sleep hypoventilation due to mutation in the skeletal muscle $\alpha$-actin (ACTAI) gene. Neuromuscul Disord 200I, I I:35-40.

74. Kaindl AM, Ruschendorf F, Krause S, Goebel HH, Koehler K, Becker C, Pongratz D, Muller-Hocker J, Nurnberg P, Stoltenburg-Didinger G, Lochmuller H, Huebner A: Missense mutations of ACTAI cause dominant congenital myopathy with cores. J Med Genet 2004, 41:842-848.

75. Carmignac V, Salih MA, Quijano-Roy S, Marchand S, Al Rayess MM, Mukhtar MM, Urtizberea JA, Labeit S, Guicheney P, Leturcq F, Gautel M, Fardeau M, Campbell KP, Richard I, Estournet B, Ferreiro A: Cterminal titin deletions cause a novel early-onset myopathy with fatal cardiomyopathy. Ann Neurol 2007, 61:340-35I.

76. Bertini E, Bosman C, Bevilacqua M, Ricci E, Gagliardi GM, Parisi F, Servidei S, Dionisi-Vici C, Ballerini L: Cardiomyopathy and multicore myopathy with accumulation of intermediate filaments. Eur J Pediatr 1990, 149:856-858.

77. Maidment SL, Ellis JA: Muscular dystrophies, dilated cardiomyopathy, lipodystrophy and neuropathy: the nuclear connection. Expert Rev Mol Med 2002:I-2I.

78. Willemsen MAAP, van Oort AM, ter Laak HJ, Sengers RCA, Gabreels FJM: Multicore myopathy with restrictive cardiomyopathy. Acta Paediatr 1997, 86:127|-1274.

79. Hagberg UJM, Carroll JE, Brooke MH: Endurance exercise training in a patient with central core disease. Neurology 1980, 30:1242-1244

80. Wallgren-Pettersson C, Bushby K, Mellies U, Simonds A: $117^{\text {th }}$ ENMC workshop: Ventilatory Support in Congenital Neuromuscular Disorders: Congenital Myopathies, Congenital Muscular Dystrophies, Congenital Myotonic Dystrophy and SMA (II). April 4-6 th 2003, Naarden, the Netherlands. Neuromuscul Disord 2004, 14:56-69.
8I. Denborough MA, Forster JF, Hudson MC, Carter NG, Zapf P: Biochemical changes in malignant hyperpyrexia. Lancet 1970, I:I I37-II38

82. Messina S, Hartley L, Main M, Kinali M, Jungbluth H, Muntoni F, Mercuri E: Pilot trial of salbutamol in central core and multi-minicore diseases. Neuropediatrics 2004, 35:262-266.

83. European Malignant Hyperthermia Group [http:// www.emhg.org]
Publish with BioMed Central and every scientist can read your work free of charge

"BioMed Central will be the most significant development for disseminating the results of biomedical research in our lifetime. "

Sir Paul Nurse, Cancer Research UK

Your research papers will be:

- available free of charge to the entire biomedical community

- peer reviewed and published immediately upon acceptance

- cited in PubMed and archived on PubMed Central

- yours - you keep the copyright

Submit your manuscript here:

http://www.biomedcentral.com/info/publishing_adv.asp
BioMedcentral 